\title{
PENGGUNAAN KONSELING BERPASANGAN UNTUK MEMBANTU PESERTA DIDIK MENANGANI HAMBATAN INTERPERSONAL
}

\author{
Eko Darminto \\ Fakultas Ilmu Pendidikan, Universitas Negeri Surabaya \\ ekodarminto@unesa.ac.id \\ Retno Tri Hariastuti \\ Fakultas Ilmu Pendidikan, Universitas Negeri Surabaya
}

\begin{abstract}
Abstrak
Menjalin hubungan dengan orang lain - sering disebut sebagai hubungan sosial atau hubungan intrpersonal - merupakan salah satu kebutuhan pokok dalam kehidupan manusia. Kebutuhan untuk menjalin hubungan sosial itu sendiri bisa bersumber dari kebutuhan-kebutuhan lain seperti kebutuhan untuk berteman atau kebutuhan untuk mendapatkan bantuan dan kerjasama orang lain dalam rangka mencapai tujuan-tujuan tertentu. Meskipun menjalin hubungan sosial merupakan salah satu kebutuhan hidup utama dan dari entitasnya sebagai makhluk sosial setiap individu memiliki kemampuan bawaan untuk melakukannya, faktanya banyak individu yang mengalami hambatan. kegagalan dalam menjalin hubungan degan orang lain tak hanya menyebabkan manusia gagal dalam menbcapai tujuan-tujuannya tetapi juga beresiko mengalami gangguan psikososial seperti menarik diri, frustrasi, depresi, hingga melakukan tindakan-tindakan agresif. Bagi peserta didik, kegalan dalam menjalin hubungan sosial tak hanya menyebabkan ganguan psikososial namun juga berpotensi menyebabkan kegagalan akademik. Oleh karena itu lembaga pendidikan perlu memilii programprogram guna memperkembangkan keterampilan membangun relasi sosial bagi peserta didik. Bimbingan dan konseling sekolah menjadi bagian integral dari sekolah yang memiliki peran penting dalam mengembangkan program ini. Artikel ini ingin mengetengahkan suatu gagasan konseptual tentang penggunaan Pair Counseling sebagai suatu metode bimbingan guna menangani berbagai bentuk hambatan dalam relasi sosial. Metode ini didasarkan pada teori pemahaman interpersonal dan memusatkan perhatian pada pengembangan kemauan dan kemampuan mengambil perspektif orang lain guna menanagani berbagai hambatan interpersonal.
\end{abstract}

Kata kunci: hubungan sosial, pair counseling, hambatan interpersonal, perspective taking.

\begin{abstract}
Relationships with other people - often referred to as social relationships or relationships intrpersonal is one of the basic necessities of human life. The need to establish a social relationship itself can be sourced from other needs such as the need to make friends or the need for assistance and cooperation of others in order to achieve certain goals. Although social relationships is one of the major necessities of life and of entities as social beings every individual has the innate ability to do so, the fact that many individuals experiencing barriers. failure in relationships degan other people not only cause human menbcapai failed in its objectives but also risk experiencing psychosocial disorders such as withdrawal, frustration, depression, to undertake aggressive actions. For learners, kegalan in social relationships not only cause psychological disorders but also potentially lead to academic failure. Therefore, educational institutions need memilii programs to develop skills to build social relationships for learners. School guidance and counseling becomes an integral part of the school which has an important role in developing this program. This article would like to set forth a conceptual idea about the use of Pair Counseling as a guidance method to handle various forms of barriers in social relations.
\end{abstract}

Keywords: Social relationships, the pair counseling, interpersonal barriers, perspective taking.

\section{PENDAHULUAN}

Menjalin hubungan dengan orang lain sering disebut dengan istilah membangun relasi sosial, interaksi sosial, atau hubungan interpersonal - merupakan kebutuhan tak bisa dilepaskan dari kehidupan manusia. Manusia memiliki banyak kebutuhan dan untuk memenuhinya ia harus berkomunikasi, berafiliasi, bergabung, bekerjasama dengan atau meminta bantuan orang lain. dengan menjalin hubungan atau berinteraksi dengan orang lain, setiap manusia bisa mengatasi kesepian, memperoleh rasa aman, dan mendapatkan bantuan atau dukungan untuk menvcapai banyak tujuan. Bahkan kebutuhan untuk menjalin hubungan dengan orang lain merupakan manifestasi dari fitrah manusia sebagai makhluk sosial (di samping makhluk individu). 
Banyak ahli psikologi telah menegaskan pentingnya manusi harus menjalin hubungan dengan orang lain. Misalnya McClelan (1957;2015) dalam teorinya tentang motivasi berprestasi menyebutkan kebutuhan untuk berhubungan dengan orang lain - yang ia konseptualisasikan dengan istilah kebutuhan untuk berafiliasi afiliasi (need for afiliation) atau keinginan untuk memiliki hubungan yang bersahabat dan intim dengan orang lainsebagai salah satu motif dasar manusia. Laurence Steinberg (1983; 2002; 2005), seorang ahli psikologi perkembangan, juga menegaskan bahwa menjalin hubungan akrab dengan orang lain - yang mengkonseptualisasikan hubungan ini dalam istilah intimacy (hubungan intim) - merupakan isu penting dalam sepanjang hayat kehidupan, namun khususnya penting pada periode remaja. Pada periode remaja, menjalin hubungan intim merupakan salah satu isu psikososial - semacam tugas perkembangan - yang harus diselesaikan secara berhasil oleh setiap individu. Steinberg (2005) mendefinisikan hubungan intim ini bukan dalam arti (konotasi) seksual atau fisik/biologis, melainkan suatu bentuk hubungan sosial yang lebih bersifat emosional yang melibatkan keterikatan, cinta dan kasih sayang (attachment). Kegagalan dalam membangun hubungan intim dengan orang lain menyebabkan remaja beresiko mengalami berbagai gangguan psikososial seperti dilanda kecemasan, depresi, agresi, menyalahgunaan obat, dan bahkan bunuh diri.

Keberhasilan dalam menjalin hubungan dengan orang lain ditandai oleh beberapa kualitas seperti adanya kepedulian, perawatan, kesediaan untuk membuka diri, menolong, dan berbagi satu sama lain (Steinberg, 2005). Keterlibatan aspekaspek pribadi secara penuh, jujur, dan terbuka juga dapat digunakan sebagai indikator bagi hubungan yang berkualitas. Keterlibatan aspek-aspek pribadi secara terbuka dan jujur dalam suatu hubungan mensifati suatu bentuk hubungan sosial yang paling tinggi. Bentuk hubungan ini disebut sebagai hubungan interpersonal. Terjalinnya hubungan sosial yang bersifat interpersonal memungkinkan terjadinya hubungan sosial yang harmonis (tiada konflik) antar manusia, karena setiap manusia yang melakukan hubungan tersebut bisa saling memahami, menerima, empatik, saling percaya, dan menghargai satu sama lain, serta menghindari (tidak melakukan) tindakan-tindakan yang dapat melukai perasaan dan fisik orang lain. Dapat dikatakan, hubungan interpersonal adalah hubungan antar manusia yang penuh dengan respek (respectfull) dan melibatkan aspek-aspek pribadi ke dalam hubungan.

Harry Stack Sullivan (1892-1949), salah seorang murid Freud setelah Adler, Jung, dan Erikson, menegaskan pentingnya hubungan interpersonal bagi individu dalam kehidupan sehari-hari. Melalui teori yang dikembangkannya, psikologi interpersonal dan teori psikoterapi interpersonal, Sullivan (Burger, 2004; Morgan, 2014) menegaskan bahwa hubungan intrpersonal menjadi faktor penyebab bagi keberhasilan hidup dan gangguan psikologis yang ia konseptualaisasikan dalam istilah sakit mental (mental illnesses). Gangguan mental individu daat diteluri penyebabnya pada cara bagaimana individu menjalin hubungan atau berinteraksi dengan orang secara intrpersonal. Kegagalan dalam menjalin hubungan dengan orang lain bisa menyebabkan gangguan mental mulai dari rasa kesepian (loneliness) hingga sisoprenia (schizophrenia). Bahkan dalam kajian perkembangan, Sullivan (Steinberg, 2005) menegaskan bahwa perkembangan psikologis individu dalam dipahami lebih baik bila dilihat dari sudut pandang hubungan interpersonal. Perkembagan individu dalam seluruh siklus kehidupan, namun khususnya pada periode remaja, berkaitan dengan upaya-upaya memuaskan atau mengubah kebutuhan interpersonal. Meskipun teori Sullivan tidak begitu populer - bahkan saat ini pun kita mungkin tidak banyak menemukan diskursus teori ini baik dalam forum seminar maupun perkuliahan, menurut Steinberg (2005) banyak penelitian memberikan data empirik yang mengkonfirmasi apa yang dihipotesiskan oleh Sullivan.

Dampak dari kegagalan dalam menjalin hubungan dengan orang lain pada gangguan psikologis juga telah ditegaskan dalam teori psikologi dan teori konseling eksistensial dan Gestalt (lihat Corey, 2012). Kedua teori ini menegaskan bahwa ketidak sanggupan individu untuk berinteraksi dengan lingkungan sosialnya secara memuaskan - yang dikonseptualisasikan dalam istilah kontak (contact) - menyebabkan individu menarik diri, cemas, merasa kesepian, dan depresi. Dalam psikologi Gestalt dikemukakan bahwa orang bisa mengalami gangguan emosi (dan perilaku) jika ia tidak membangun hubungan sosial (kontak) dengan lingkungan sosialnya. Demikian pula dalam psikologi eksistensial juga ditegaskan bahwa gangguan perilaku dapat bersumber dari kegagalan orang untuk membangun relasi yang bermakna dengan orang lain. Dalam spektrum yang lebih luas, kegagalan dalam membangun hubungan, khususnya hubungan sosial antara kelompok, dapat menimbulkan perpecahan, disintegrasi, dan peperangan. Karen Horney, murid Freud yang lain setelah Sulivan, juga mengembangkan teori konseling yang berbasis hubungan interpersonal, yakni teori psikoanalitik interpersonal (Cloninger, 2008) yang juga menegaskan pengaruh hubungan interpersonal pada kesehatan psikologis. Menurut Horney, berbagai gangguan psikologis/perilaku disebabkan oleh adanya isu atau masalah-hubungan interpersonal yang tak terpecahkan, khususnya 
konflik interpersonal dengan orang tua atau orngorang penting dalam kehidupan individu di masa lalu. Jadi, seperti halnya Freud, Horney setuju bahwa pengalaman masa lalu berpengaruh pada kehidupan saat ini. Namun bedanya, bila Freud menekankan pada pemenuhan kebutuhan seksual, Horney lebih menekankan pada isu-isu interpersonal.

Dari apa yang dikemukakan dapat diperoleh kesimpulan bahwa menjalin hubungan dengan orang lain merupakan salah satu kebutuhan dasar manusia. Keberhasilan dalam menjalin hubungan memungkinkan manusia dapat memenuhi kebutuhan-kebutuhan lain dan mencapai berbagai tujuan dengan cara yang lebih mudah. Sebaliknya, kegagalan dalam membangun hubungan dengan orang lain - dalam konteks ini dikonseptualisasikan dalam istilah mengalami hambatan interpersonal - berpotensi menyebabkan individu mengalami gangguan psikososial bahkan menderita penyakit mental. Permasalahannya adalah bahwa tak setiap individu manusia - karena beberapa alasan - tak memiliki kesanggupan untuk membangun hubungan interpersonal dengan orang lain, beberapa di antara manusia mengalami hambatan dan membutuhkan bantuan. Maraknya berbagai bentuk tindak kekerasan terhadap orang lain yang dilakukan oleh anak, remaja, dan orang dewasa yang grafiknya terus menjukkan tren meningkat dari tahun ke tahun, demikian pula banyaknya anak dan remaja yang mengalami gangguan emosi seperti depresi, rasa benci, amarah dan berbagai bentuk perilaku menarik diri, alinasi, mangkir dari sekolah (membolos), menyalahgunakan narkoba, dapat digunakan sebagai indikator bahwa beberapa anak dan remaja mengalami hambatan interpersonal.

Banyaknya anak dan remaja, khususnya anak dan remaja di kalangan peserta didik yang mengalami hambatan interpersonal tentu membawa implikasi langsung pada lembaga pendidikan, khususnya bimbingan dan konseling untuk mengembangkan progam-program bimbingan guna membantu peserta didik menangani hambatan interpersonal. Artikel ini ingin mengetengahkan suatu gagasan konseptual tentang penggunaan suatu model atau metode konseling yang secara teoretik efektif untuk membantu peserta didik anak dan remaja menangani hambatan interpersonal, yakni konseling berpasangan (pair counseling). Untuk bahasan selanjutnya metode konseling ini disingkat PC.

\section{METODE}

\section{Konsep}

$P C$ merupakan suatu bentuk intervensi psikologis dalam bidang konseling dan psikoterapi berbasis teori-teori perkembangan untuk membantu anak belajar keterampilan untuk menjadi teman yang lebih baik, membangun dan mempertahankan hubungan abadi, dan melakukan negosiasi yang lebih efektif dalam suatu hubungan (Karcher, 2002, Karcher \& Lewis, 2002; Selman \& Cohen, 1990). PC dilaksanakan dengan cara memasangkan dua anak dalam suatu proses konseling kemudian memfasilitasi kedua anak untuk melakukan berbagai aktivitas yang terpusat pada upaya mencapai interaksi sosial yang matang.

PC sesungguhnya merupakan hasil inovasi (pengembangan) dari $P T$ yang sudah berkembang lebih dahulu selama hampir tiga dasa warsa dalam bidang psikologi klinis dan psikologi perkembangan. $P T$ digunakan untuk menangani anak dan remaja yang mengalami gangguan emosi dan perilaku tergolong akut melalui suatu terapi berjangka waktu panjang (Karcher, 2002). Sedangkan PC digunakan untuk menangani gangguan yang tergolong ringan hingga moderat dan individu masih memiliki kesadaran penuh terhadap dirinya. Oleh karena itu, konselor harus melakukan kontrol yang lebih tinggi pada konseli bila ia menerapkan PT. Meskipun memiliki sedikit perbedaan, antara PC dan PT memiliki kesamaan, yakni keduanya merupakan terapi bermain dengan cara membentuk pasangan dari dua anak dan mengintegrasikan dinamika dan praktek yang terpusat pada anak.

Melalui PC konselor membangun konteks sosial-interpersonal yang suportif kepada konseli untuk mempraktekkan cara-cara yang lebih efektif untuk berinteraksi dengan orang lain. dalam bentuknya yang operasional, dlaam PC anak konselor membelajarkan konseli untuk mempraktekkan keterampilan-keterampilan sosial yang efektif untuk menangani hambatan interpersonal dan menjalin hubungan dengan orang lain. PC telah banyak banyak digunakan untuk membantu anak dan remaja yang memiliki hambatan interpersonal seperti pemalu, agresif, dan menarik diri, dan terisolir.

\section{HASIL DAN PEMBAHASAN}

\section{Dasar Teori}

PC pertama kali dikembangkan oleh Karcher dan telah banyak mendapatkan dukungan data empirik untuk menguji keefektifannya. Menurut Karcher (2002) didasarkan pada beberapa asumsi. Asumsi pertama adalah bahwa banyak individu, khususnya anak dan remaja, yang mengalami kesulitan karena mereka kurang menguasai keterampilan sosial yang mencukupi guna menjalin hubungan sosial yang efektif dengan orang lain (Karcher, 2002; Karcher \& Lewis, 2002). Kegagalan dalam membangun hubungan sosial dapat disebabkan oleh banyak faktor, salah satunya adalah karena mereka tidak mau dan tidak mampu untuk memahami, 
menerima, dan menghargai orang lain. dalam banyak litertur psikologi dan klinis, kemamuan dan kemampuan untuk memahami, menerima, dan menghargai orang lain merupakan dimensi-dimensi dari hubungan interpersonal. Asumsi kedua, bahwa dengan membantu anak mengembangkan kemampuan untuk memahami orang lain dan membuat respon secara secara tepat sesuai dengan kondisi mental orng lain dapat mencegah (menghindarkan) individu dari alinasi, penolakan, isolasi, depresi, dan tindakan agresif, bahkan berprestasi di bawah potensi (underachievement) (Karcher, 2002). PC dikondisikan sebagai metode bantuan untuk membantu anak menangani berbagai kesulitan sosial dengan cara memberikan kesempatan untuk mempelajari, mengembangkan, dan menguji keterampilan sosial secara lebih efektif dalam berhubungan dengan orang lain.

Keterampilan sosial yang efektif yang dimaksudkan adalah suatu cara bertindak atau merespon yang sesuai dengan kondisi mental orang lain. Oleh karena itu, sebelum membentuk respon, individu perlu lebih dahulu memahami kondisi mental orang. Kondisi mental orang lain ini meliputi perasaan (apa yang dirasakan), pikiran (apa yang dipikirkan), dan motivasi (apa yang menjadi alasan) orang lain sehingga orang lain memiliki pendapat atau penilaian yang berbeda, atau melakukan tindakan yang berbeda (Epley \& Waytz, 2009; Gehlbach, 2012; Kuzma, 2008; Rubenstein, 2012). Dalam literatur, kemampuan untuk memahami kondisi mental orang lain dan dapat bertindak secara efektif sesuai dengan kondisi mental orang lain dikonseptualisasikan dalam istilah mengambil perspektif orang lain (perspective taking). Makna simpel dari mengambil perspektif orang lain - untuk bahasan selanjutnya disingkat MPO - adalah dapat memahami, menerima, dan menghargai sudut pandang orang lain dalam melihat atau mengalami suatu situasi, peristiwa, atau realitas (Casanave, 2010; Davis; dalam Trotchell, dkk., 2011; Fields, 2010; Goldstein, 2014). Atas dasar ini maka PC didasarkan pada teori MPO.

Dalam literatur dapat ditemukan teori atau model teoretik tentang mengambil perspektif orang lain - untuk bahasan selanjutnya disingkat MPO namun secara khusus PC didasarkan pada tori MPO yang dikembangkan oleh Robert L. Selman. Teori MPO Selman dikembangkan pertama kali pada tahun 1980 dengan nama teori pemahaman interpersonal (interpersonal understanding). Selman adalah ahli psikologi sosial yang kemudian banyak memusatkan perhatian pada penerapan psikologi sosial dalam bidang pendidikan. Selman (1980) mendeskripsikan pemahaman interpersonal sebagai kemampuan MPO - untuk bahasan selanjutnya disingkat KMPO - dalam situasi sosial. Selman memiliki keyakinan bahwa KMPOmenjadi kemampuan yang inti untuk memahami pikiran, kebutuhan, dan keyakinan orang lain dan membangun landasan yang kondusif untuk memperkembangkan hubungan sosial yang efektif. KMPO akan mendasari strategi negosiasi interpersonal (interpersonal negotiation strategy, disingkat INS). Berdasarkan pendapat Selman ini maka Karcher (2002) memiliki keyakinan bahwa KMPO akan mendorong pemahaman interpersonal dan pemahaman interpersonal ini menentukan kesadaran individu tentang dampak sosial dari perbuatannya. Kesadaran ini pada gilirannya akan menjadi dasar bagi individu untuk menggunakan INS.

Berdasarkan hasil penelitiannya, Selman (Selman, 1980, Cadwick \& Ralston, 2010; Roan, dkk., 2011 ) menyimpulkan bahwa KMPO tidak bersifat bawaan namun berkembang dari pengalaman dan pembelajaran. KMPO mulai berkembang ketika anak berusia tiga tahun dan mencapai puncaknya pada usia 12 tahun ketika mereka telah mencapai taraf kemampuan berpikir abstrak. Banyak ahli lain mendukung keyakinan Selman ini. Misalnya Epley \& Waytz (2009), menyatakan bahwa KMPO bukanlah suatu kemampuan yang telah terbentuk ketika individu lahir, tetapi berkembang dari waktu ke waktu.Perkembangan KMPO berjalan melalui empat tahapan, yakni: tahap egosentris, tahap perspektif pihak 1, tahap prspektif pihak 2, tahap perspektif bersama, dan tahap perspektif pihak ketiga atau perspektif sosial (Cadwick \& Ralston, 2010; Roan, dkk., 2011; Yeath \& Selman, 1989). Berikut adalah penjelasan dari ke empat tahapan KMPO tersebut.

Pada tahap egosentris, anak belum bisa memahami mengapa orang lain memperlihatkan perasaan, pendapat, atau tindakan yang berbeda dengan dirinya ketika melihat atau mengalami suatu situasi yang sama. Dalam banyak kasus, banyak anak cenderung impulsif dan berharap orang lain memiliki perasaan, pendapat, dan tindakan yang sama dengan dirinya.

- $\quad$ Pada tahap perspektif satu pihak, anak sudah bisa mengerti mengapa orang lain merespon secara berbeda dengan dirinya. Mereka bisa memahami bahwa orang lain membentuk respon yang berbeda karena mereka memiliki pengetahuan, pengalaman, dan latar belakang yang bebreda dengan dirinya.

- $\quad$ Pada tahap perspektif pihak kedua, anak sudah mulai mencoba untuk mengalami sesuatu seperti bagaimana orang lain mengalaminya dan berusaha memahami perasaan, pikiran, dan tindakan orang lain. Jadi anak tidak lagi bertindak secara impulsif ketika menemukan orang lain memperlihatkan respon yang berbeda. 
- Pada tahap perspektif bersama, anak mampu menggabungkan perspktif dirinya dan perspektif orang lain menjadi perspektif bersama. Pada fase perspektif sosial, anak mampu memahami bahwa perspektif pihak ketiga dipengaruhi oleh nilai-nilai dalam masyarakat luas.

Tahapan perkembangan KMPO dalam perspektif Selman tersebut diilustrasikan pada tabel 1. Tabel 2.3 menggambarkan tahapan perkembangan kemampuan MPO beserta dengan usia kronologis dan indikator kemampuannya dalam teori Selman sebagaimana dikutip dari Yeath \& Selman (1989: 78).

Perkembangan KMPO tersebut, menurut Selman (1980) dipengaruhi oleh pengalaman, khususnya pengalaman terstruktur berupa bimbingan dan latihan. Namun demikian, Selman mengakui bahwa faktor utama yang mendukung perkembangan KMPO adalah kemampuan kognitif. Artinya, dampak dari pengalaman pada perkembangan KMPO untuk tiap individu tidak sama tergantung pada perkembangan kemampuan kognitifnya. Jika pengalaman diberikan pada usia yang tepat dan sesuai dengan tingkat perkembangan kognitifnya, maka upaya ini akan memberikan dampak yang signifikan. Oleh karena itu kelambatan dalam perkembangan kognitif akan berpengaruh pada perkembangan KMPO.

Berdasarkan teori KMPO Selman tersebut tampak jelas bahwa upaya-upaya intervensi untuk meningkatkan KMPO tidak akan sia-sia asalakan dilakukan dengan cara yang tepat. Dalam kaitannya dengan teori ini maka PC diterapkan dengan cara membantu individu menguasai KMPO pada tingkat yang paling tinggi (tahap 4) dengan cara mengalami dan belajar menguasai KMPO dari tingkatan paling bawah (egosentrris) menuju paling tinggi (sosial). Perbedaan dalam perkembangan KMPO ini selalu dapat ditemukan karena faktanya tak semua anak mengalami hambatan dalam perkembangan kognitifnya (Eppley \& Waytz, 2009). Hambatan dalam perkembangan MPO antara lain disebabkan oleh karena individu terbiasa menggunakan respon egosentris, kurang latihan, dan kurangnya pengetahuan (Epley, 2008).

Dari kajian teori Selman tersebut diperoleh pemahaman bahwa terdapat sumbersumber internal dan eksternal dalam mempengaruhi KMPO. Sumber eksternal adalah pengaruh lingkungan berupa pemberian pengalaman, khususnya pengalaman terstruktur berupa bimbingan dan latihan yang dapat mengaktifkan proses-proses kognitif untuk mengambil perspektif orang lain. Sumber internal adalah kemampuan kognitif, tepatnya kemampuan berpikir abstrak. Jadi pada usia remaja ketika setiap individu telah mencapai taraf kemampuan berpikir abstrak, setiap anak seharusnya telah mencapai taraf KMPO paling tinggi, yakni bisa menggabungkan atau mengkoordinasikan berbagai perspektif menjadi perspektif bersama atau yang disebut sebagai perspektif sosial.

Tabel 1. Tahapan Perkembangan KMPO dalam teori Selman

(disalin dari Yeath \& Selman, 1989: 78).

\begin{tabular}{|c|c|c|}
\hline Tahapan & Usia & Deskripsi KMPO Anak \\
\hline $\begin{array}{l}\text { Tahap 1: } \\
\text { perspektif } \\
\text { egosentris }\end{array}$ & $3-6$ & 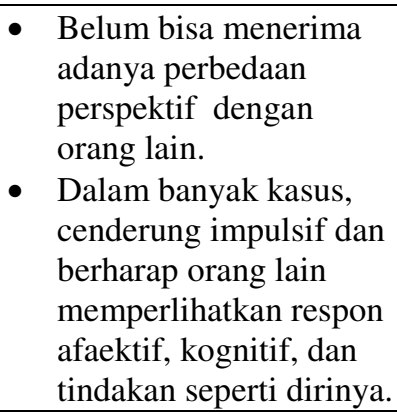 \\
\hline $\begin{array}{l}\text { Tahap 2: } \\
\text { perspektif } \\
\text { pihak satu }\end{array}$ & $6-8$ & $\begin{array}{l}\text { Dapat memahami } \\
\text { bahwa adanya } \\
\text { perbedaan respon } \\
\text { karena orang memiliki } \\
\text { pengetahuan, } \\
\text { pengalaman, dan latar } \\
\text { belakang yang berbeda. } \\
\text { Mampu } \\
\text { mengembangkan } \\
\text { dugaan bahwa orang } \\
\text { lain dapat mengubah } \\
\text { pandangannya tentang } \\
\text { suatu situasi jika } \\
\text { mereka diberi } \\
\text { informasi/pengetahuan } \\
\text { tambahan }\end{array}$ \\
\hline $\begin{array}{l}\text { Tahap 2: } \\
\text { perspektif } \\
\text { pihak dua }\end{array}$ & $8-10$ & $\begin{array}{l}\text { - Mulai mencoba untuk } \\
\text { merasa, berpikir, dan } \\
\text { bertindak seperti orang } \\
\text { lain dan berusaha } \\
\text { memahami respon } \\
\text { orang lain. } \\
\text { Mulai memahami } \\
\text { bahwa orang lain dapat } \\
\text { melakukan hal yang } \\
\text { sama dengan dirinya. } \\
\text { Dapat menjelaskan } \\
\text { suatu situasi pada orang } \\
\text { lain dan mengubah } \\
\text { pandangan orang lain } \\
\text { dengan cara } \\
\text { memberikan informasi } \\
\text { atau fakta baru . }\end{array}$ \\
\hline $\begin{array}{l}\text { Tahap 3: } \\
\text { perspektif }\end{array}$ & $10-12$ & $\begin{array}{l}\text { Mampu mengambil } \\
\text { perspektif yang lebih } \\
\text { abstrak dalam }\end{array}$ \\
\hline
\end{tabular}




\begin{tabular}{|c|c|c|}
\hline bersama & & $\begin{array}{l}\text { hubungannya dengan } \\
\text { orang lain dan } \\
\text { mengkoordinasikan dua } \\
\text { perspektif yang berbeda } \\
\text { menjadi perspektif } \\
\text { bersama. } \\
\text { Dapat membayangkan } \\
\text { bagaimana dirinya dan } \\
\text { orang lain dipandang } \\
\text { oleh pihak ketiga. }\end{array}$ \\
\hline $\begin{array}{l}\text { Tahap 4: } \\
\text { perspektif } \\
\text { sosial }\end{array}$ & $\begin{array}{c}12 \\
\text { tahun } \\
\text { ke } \\
\text { atas }\end{array}$ & $\begin{array}{l}\text { - Pada tingkat/usia ini } \\
\text { semua anak dapat } \\
\text { memahami bahwa } \\
\text { perspektif pihak ketiga } \\
\text { dipengaruhi oleh nilai- } \\
\text { nilai yang berlaku di } \\
\text { dalam masyarakat luas. }\end{array}$ \\
\hline
\end{tabular}

\section{Implementasi}

Tujuan umum PC adalah membantu anak belajar menjadi teman yang baik, membangun dan mempertahankan hubungan yang lestari, dan membuat negosiasi yang efektif dengan orang lain. Tugas konselor adalah membantu anak untuk mengelola keakraban dan kemandirian dalam situasi hubungan dengan menerapkan keterampilan sosial (KMPO) yang tepat sesuai dengan usianya. Tujuan ini dicapai melalui aktivitas-aktivitas perkembangan yang melibatkan permainan dalam kelompok dan refleksi diri yang mendorong pemahaman dan keterampilan sosial. Tujuan khusus dari PC adalah membantu individu menguasai KMPO tingkat tinggi (tahap keempat atau perspektif sosial pada teori Selman) dengan cara membelajarkan individu beralih dari KMPO tahap rendah ke tahap di atasnya. Dalam PC konselor harus membelajarkan anak dan menstruktur kesempatan bagi terjadinya perkembangan sembari memberikan peluang bagi kemandirian, spontanitas dalam bermain, dan bertindak secara autentik dengan anak lain.

PC dilaksanakan dengan membentuk pasangan atau pasangan-pasangan. Setiap pasangan terdiri atas dua konseli. Konseli adalah individu atau peserta didik yang telah diidentifikasi mengalami hambatan sosial dan telah menyatakan memiliki komitmen untuk mengubah dirinya menjadi lebih baik.

Untuk mendorong penguasaan keterampilan KMP dari tahapan paling rendah menuju tahapan paling tinggi, PC menggunakan tiga teknik yang diusulkan oleh Selman \& Schultz (1990) - yang disebut sebagai teknik intervensi perkembangan (Karcher, 2002), yaitu: empowering, linking, dan enabling. Ketiga teknik tersebut digunakan oleh konselor untuk membantu setiap pasangan subyek bekerja sesuai dengan tingkat kematangan sosial dan perkembangannya, mulai dari KMPO pada tingkat terendah (egosentris) menuju KMPO tingkatan paling tinggi (perspektif sosial). Berikut adalah penggunaan masing-masing teknik dalam proses konseling sebagaimana dikemukakan oleh Karcher.

- Empowering. Teknik ini digunakan untuk membantu konseli beralih dari tahap egosentris ke tahap perspektif pihak satu dengan cara mendorong konseli mengartikulasikan keyakinan, keinginan, tujuan, dan perasaanya sendiri.

- Linking. Teknik ini digunakan untuk membantu konseli menggabungkan perspektif dirinya dengan perspektif orang lain, yakni membantu pasangan untuk mengkoordinaksikan perspektif mereka. Jadi teknik ini digunakan oleh konselor untuk membantu subyek maju dari kemampuan KMPOpihak satu menuju KMPO pihak kedua. Terjadinya koordinasi perspektif memungkinkan pasangan untuk bekerja sama membuat keputusan tentang tindakan apa yang paling tepat untuk merespon situasi/stimuli.

- Enabling. Teknik ini digunakan untuk membantu pasangan melihat akibat jangka panjang dari tindakan individual pada hubungan bersama/kolektif atau membantu pasangan mengambil perspektif pihak ketiga.

Untuk memfasilitasi agar proses konseling berjalan dalam situasi yang menyenangkan, PC menggunakan media bermain atau permainan. Aktivitas bermain dalam PC berfungsi untuk mendorong perkembangan kognitif, khususnya untuk mengembangkan KMPO. Jenis permainan yang dipilih perlu dipertimbangkan atas dasar nilai terapeutiknya untuk memfasilitasi proses-proses ekspresi diri yang dinamis (misalnya proyeksi), bermain fantasi, dan permainan simbolik spontan (Karcher, 2002). Jenis-jenis permainan itu misalnya adalah boneka, cerita lucu, atau magic-ball (dalam dunia anak Amerika, untuk di Indonesia perlu dicarikan jenis yang sepadan). Jenis permainan lain juga harus tersedia sehingga anak-anak tidak merasa dipaksa untuk melakukan aktivitas tertutup yang membuat mereka merasa tidak nyaman. 


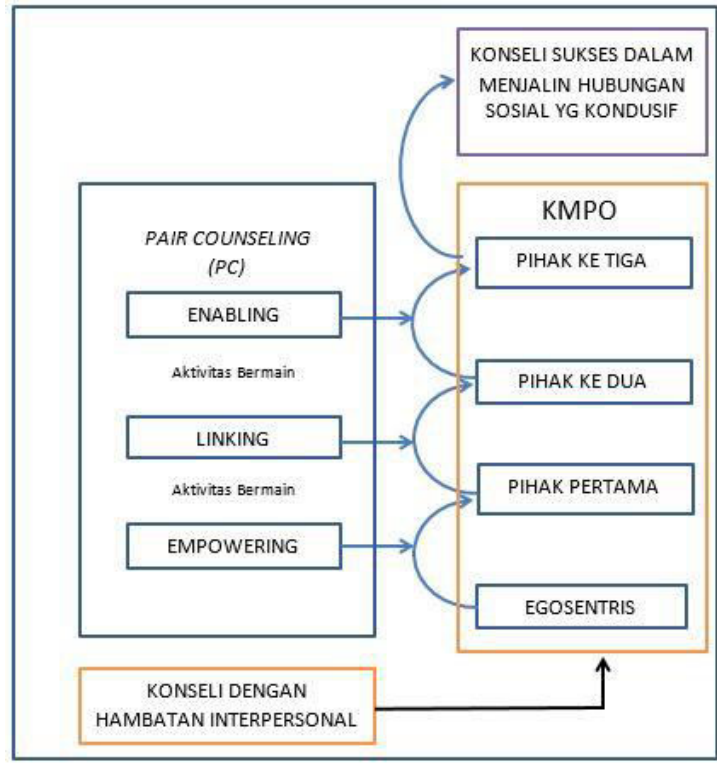

Bagan 1. Model Koneptual penerapan PC untuk menangani hambatan Interpersonal

Ada beberapa jenis permainan yang secara khusus digunakan untuk memfasilitasi anak berkembang dari tahapan-tahapan KMPO. Jenis yang pertama berupa permainan atau aktivitas yang bersifat fisik, impulsif, misalnya bermain bola basket. Permainan ini digunakan untuk memfasilitasi terjadinya peningkatan dari kemampuan KMPO egosentris menuju KMPO tahap pihak satu. Jenis permainan kedua, digunakan untuk memfasilitasi peralihan dari KMPO pihak satu ke KMPO pihak dua. Jenis permainan ini berbasis (memiliki) aturan sederhana yang memungkinkan anak merasa kompeten dalam mengkoordinasikan perspektif dan perilaku mereka. Permainan-permainan ini mengandung aktivitas yang memungkinkan anak-anak berbicara satu sama lain, memperdalam hubungan, dan berbagi pengalaman secara akrab. Jenis permainan ketiga adalah permainan yang dapat menumbuh kembangkan pertemanan yang akrab dan mendalam. Permainan ini digunakan untuk memfasilitasi terjadinya peningkatan KMPO pihak ke dua menuju KMPO pihak tigas (sosial). Pemainan ini harus mampu mendorong anak untuk saling membuka diri dan saling berceritera satu sama lain, memecahkan amsalah bersama, dan merasa nyaman dalam kebersamaan mereka. Model implementasi ini diilustrasikan pada bagan.

\section{PENUTUP}

\section{A. Kesimpulan}

Menjalin hubungan dengan orang lain merupakan salah satu kebutuhan dasar manusia. Keberhasilan dalam menjalin hubungan memungkinkan manusia dapat memenuhi kebutuhan-kebutuhan lain dan mencapai berbagai tujuan dengan cara yang lebih mudah. Individu yang gagal dalam menjalin hubungan sosial secara efektif - disebut sebagai orang yang mengalami hambatan interpersonal. Individu ini berpotensi mengalami berbagai bentuk gangguan psikososial. Keberhasilan dalam menjalin hubungan dengan orang lain dapat ditandai oleh kesedian individu untuk melibatkan aspek-aspek pribadinya secara penuh dalam situasi hubungan. Kualitas hubungan semacam ini disebut hubungan interpersonal, dan orang yang mengalami kegagalan dalam menjalin hubungan interpersonal diidentifikasi sebagai orang yang mengalami hambatan interpersonal.

$$
\text { Meskipun menjakin hubungan }
$$
interpersonal dengan orang lain merupakan kebutuhan dasar, dalam arti mendasari bagi pemenuhan kebutuhan-kebutuhan hidup yang lain, faktanya tak setiap individu manusia - karena beberapa alasan - tak memiliki kesanggupan untuk membangun hubungan interpersonal dengan orang lain, beberapa di antara manusia mengalami hambatan dan membutuhkan bantuan. Maraknya berbagai bentuk tindak kekerasan terhadap orang lain yang dilakukan oleh anak, remaja, dan orang dewasa yang grafiknya terus menjukkan tren meningkat dari tahun ke tahun, demikian pula banyaknya anak dan remaja yang mengalami gangguan emosi seperti depresi, rasa benci, amarah 
dan berbagai bentuk perilaku menarik diri, alinasi, mangkir dari sekolah (membolos), menyalahgunakan narkoba, dapat digunakan sebagai indikator bahwa beberapa anak dan remaja mengalami hambatan interpersonal.

Hambatan interpersonal bisa disebabkan oleh banyak faktor, salah satunya karena orang tak dapat mengambil perspektif orang lain dalam situasi hubungan. Mengambil perspektif orang lain terjadi bila orang bisa memahami dan menghargai perasaan, pikiran, dan tindakan orang lain dalam merespon suatu situasi dan dapat bertindak secara efektif (tanpa menimbulkan konflik) sesuai dengan kondisi mental orang lain. Kemampuan ini tidak bersifat bawaan tapi dapat berkembangn melalui pengalaman dan pembelajaran. Kemampuan ini berkembang sesuai dengan perkembangan kemampuan kognitif. Secara teoretik, pada periode remaja akhir setiap individu idealnya telah mencapai kemampuan ini pada taraf tertinggi, namun beberapa diantaranya mengalami hambatan.

Pair counseling (PC) berisikan aktivitasaktivitas bermain untuk membelajarkan individu menguasai kemampuan mengambil perspektif orang lain mulai dari tingkat aling rendah hingga paling tinggi. Oleh karena itu secara teoretik PC dapat digunakan sebagai metode intervensi guna membantu individu menangani hambatan interpersonal. PC diimolementasikan melalui tiga teknik, yakni: empowering, linking, dan enabling. ketiga teknik diimplementasikan secara integratif untuk membelajarkan individu keterampilanketerampilan yang mengarahkan pada penguasaan kemampuan untuk mengambil perspektif orang lain. Metode ini belum dipraktekkan oleh konselor dalam konteks pendidikan di Indonesia dan oleh karena itu disarankan agar para konselor di Indonesia mau untuk mengkaji secara empiris berkenaan dengan fisibiltas, aplikabilitas, dan keefektifan metode ini guna membantu peserta didik menagani berbagai permasalahan sosial.

\section{DAFTAR PUSTAKA}

Cloninger, S. 2008. Theories of Personality. Fifth ed. New Jersey: Pearson, Prentice Hall.

Day, A., Howells, K., \& Mohr, P. 2008. The Develoment of CBT Programmes for Anger: The Role of Interventions to Promote Perspective Taking Skills. Behavioral and Cognitive Psychotherapy, 36, 299-312.

Egan, G. 2012. The Skilled Helper. 10 ed.

Belomont, CA: Cengage Learning

Epley, N., Morewedge, C.K., \& Keysar, B. 2004. Perspective taking in children and adults: Equivalent egocentrism but differential correction. Journal of Experimental Social Psychology, 40, 760-768.

Epley, N., Caruso, E, M., \& Bazerman. 2006. When perspective taking increases taking: Rective egoisme in social interaction. Journal of Peronality and Social psychology, 91, no. 5., 872-889.

Epley, N., \& Caruso, E,M. 2008. Perspektivetaking: Misstepping other's shoes. Handbook of Imagination and mental simulation.

Nicholas Epley, N., Caruso, E.M., \& Bazerman, M.H. 2006. When Perspective Taking Increases Taking: Reactive egoism in Social Interaction. Journal of Personality and Social Psychology, 2006, Vol. 91, No.5, pp. 872-889

Galinsky, A.D., Ku, G., \& Wang, C.S. 2005. Perspektive -Taking and self-other overlap: Fostering social bons and facilitating social coordination. Group Pocess \& Intergroup Relations, 8, 109124.

Galinsky, A.D., \& Moskowitz, G.B. 2000. Perspective Taking: Decreasing Stereotype Expression, Stereotype Accessibility, and In-Group Favoritsm. Journal of Personality and Social Psychology, 2000, Vol. 78, No. 4, pp. 708-724. 
Karcher, M.J. 2002. The principles and practice of pair-counseling: a dyadic developmental. Play therapy for agressive, withdrwn, and socially immature youth. International Journal of Play Therapy, 11, 121-147.

Karcher, M.J. 2002. The Principles and Practice of pair Counseling: A Dyadic Developmental Play Therapy for Aggressive, Withdrawn, and Socially Immature Youth. International Journal of Play Therapy, 11 (2), 121-147.

Karcher, M.J., \& Lewis, S.S. 2002. Paircounseling: The effect of a dyadic evelopmental play therapy on interpersonal understanding and externalizing behaviors. International Journal of Play Therapy, 11, 19-41.

McClelland, D. 2015. The Achievement Motive Paperback-Reprint of 1953 Edition. Martino Fine Books (June 12, 2015)

O’Brien, Konrtah, S.H., Gruhn, D., \& Hagen, A.L. 2010. Empathic Concern and Perspective Taking: Linier anda Quadratic Effects of Sge Across the Adult Life Span. The Journal of Gerontology, Series B: Psychological Sciences and Social Sciences, doi: 10, 1093/geromb/gbs055

Roan, L., Strong, B., Foss., P., Yager, M., Gehlbach, H., \& Metcalf, K. 2009. Social Perspective Taking. Arlington: United States Army Research Institute.

Selman, R. L. (1980). The growth of interpersonal understanding: Developmental and clinical analyses. New York: Academic Press.

Selman, R.L., \& Schultz. L.H. 1990. Making friend in youth: Developmental theory and pair-therapy. Chicago, IL: University of Chicago Press.
Selman, R.L. 2003. The promotion of social awareness: Powerful lesson from the partnership of developmental theory and classroom practice. New York: Russel Sage Foundation.

Schultz, L.H., \& Selman, R.L. 1989. Bridging the gap between interpersonal thought and action in early adolescence. The role of psychodinamic processes. Development and Psychopathology, 1,133-152.

Steedley, K.M., Schwartz, A.S., Levin, M., \& Luke, S.D. 2011. Social skills and academic acheveent. Evidence for Education, Vol. III, Issue 2.

Steinberg, L. 2017. Adolescence. $11^{\text {th }}$ Edition.

Boston: Mc Graw Hill. Higher Education

Trotchell, R., Loschelder, D.D., Huffmeier, J., \& Schwartz. K. 2011. Perspective taking as mans to overcome motivastional barriers in negotiations: when putting oneself into the opponent's shoes helps to walk toward agreements. Journal of Personality and Social Pathology, 4, 771-790.

Weyant, J.M. 2007. Perspective Taking as a Means of Reducing Negative Stereotyping of Individuals Who Spak English as a Second Language. Journal of Applied Social Psychology, 2007, 37, 4, pp. 703-716.

Wu, S., \& Keysar, B. 200). The effect of culture on perspective taking. Association for psycholical science, 2007, Vol. 18, No. 7, p. 600-606.

Zeng Li. 2011. Perspective Taking as a Moderator of the Relationship between Social Rejection and Altruism. International Journal of Psychological Studies, Vol. 3, No. 2, December 2011, pp. 64-75. 